\title{
Antigenic Properties of Mycoplasma Organisms and Membranes
}

\author{
By M. ARGAMAN AND S. RAZIN \\ Department of Clinical Microbiology, The Hebrew University-Hadassah Medical \\ School, Jerusalem, Israel \\ (Accepted for publication 25 August 1968) \\ SUMMARY
}

The antigenic properties of the soluble and membrane-bound proteins of Mycoplasma organisms were studied by a variety of gel-diffusion techniques. The strains tested belonged to several distinct serological groups, showing no cross-reactions. One group consisted of the Mycoplasma laidlawii strains and the other of caprine and bovine strains, which were closely related to $M y c o-$ plasma mycoides var. mycoides. The avian strains tested were serologically heterogenous. After Mycoplasma membranes were solubilized by sodium dodecyl sulphate (SDS) the antigenic properties of their membrane proteins were analysed. In immunodiffusion tests they showed a serological specificity similar to the soluble cell proteins. This specificity was not found in lipids of $M$. laidlawii membranes extracted with chloroform + methanol. In gel diffusion tests the hydrophobic protein fraction isolated from $M$. laidlawii membranes by detergent action and $\left(\mathrm{NH}_{4}\right)_{2} \mathrm{SO}_{4}$ precipitation reacted with antiserum to whole organisms, was antigenic in rabbits and there produced an antiserum which reacted with it, but not with the soluble cell proteins or membrane material solubilized in SDS.

\section{INTRODUCTION}

Biochemical and cultural properties usually are insufficient for the identification and classification of organisms of the order Mycoplasmatales. Serological properties have therefore been widely used for these purposes (Edward et al. 1967). Although a variety of serological reactions are successfully used for the identification of mycoplasmas, little is known about the cell components responsible for these reactions. Some progress has been made in the characterization of Mycoplasma antigens. Lipids, apparently located in the cell membrane, were found to be responsible for the complement-fixing ability of $M$. pneumoniae (Kenny \& Grayston, 1965; Prescott, Sobeslavsky, Caldes \& Chanock, I966; Sobeslavsky, Prescott, James \& Chanock, 1966; Lemcke, Marmion \& Plackett, 1967; Marmion, Plackett \& Lemcke, 1967). The extracted lipids, when combined with protein became highly immunogenic, stimulating high values for complement-fixing and growth-inhibiting antibodies. In contrast, the serological activity of the lipid fraction of $M$. mycoides var. mycoides was limited. Complement-fixing activity and precipitin reactions could be attributed to the galactan produced and excreted by this organism (Marmion et al. 1967). Like M. pneumoniae, $M$. fermentans was also found to possess specific lipid antigens, while the lipid extracted from $M$. hominis and $M$. pulmonis cross-reacted and had little serological activity. The major antigens in the last three Mycoplasma species appear to be protein in nature (Deeb \& Kenny, 1967; Kenny, 1967; Lemcke \& Hollingdale, 1968). 
Little has been done so far to characterize the serological properties of the Mycoplasma proteins. To the best of our knowledge all the work done so far has been concerned with the soluble cell proteins released by cell disruption. The insoluble cell proteins, mainly located in the cell membrane, have not so far been studied because of the difficulties involved in their solubilization, which is essential for their biophysical and serological characterization. Nevertheless, there is little doubt that membrane proteins, being surface antigens, play a crucial role in immunogenesis against Mycoplasma infections. Some indications that antigens present in the cell membrane combine at this site with antibody to inhibit growth of mycoplasmas were recently published (Williams \& Taylor-Robinson, 1967; Lemcke \& Hollingdale, 1968).

The cell proteins, the synthesis of which is strictly dictated by the cell genome, might be expected to contribute the most specific cell antigens, and in fact the electrophoretic patterns of Mycoplasma cell proteins have been shown to be species-specific and highly reliable tools for the identification and classification of mycoplasmas (Razin \& Rottem, 1967). The serological characterication of mycoplasma proteins is likely to help in putting the classification of these organisms on a sounder basis.

Table I. Designation of Mycoplasma strains and antisera

\begin{tabular}{|c|c|c|c|c|}
\hline Type or species & & Recovered from & Obtained from & Antiserum \\
\hline M. laidlawii & $\begin{array}{l}A(P G 8) \\
B(P G 9) \\
\text { OR }\end{array}$ & $\begin{array}{l}\text { Sewage } \\
\text { Sewage } \\
\text { Human oral } \\
\text { cavity }\end{array}$ & $\begin{array}{l}\text { D. G. ff. Edward* } \\
\text { D. G. ff. Edward* } \\
\text { Isolated in our } \\
\text { laboratory }\end{array}$ & $\begin{array}{l}\text { aA } \\
\text { aB } \\
\text { aOR }\end{array}$ \\
\hline $\begin{array}{l}\text { M. mycoides } \\
\text { var. mycoides }\end{array}$ & $\begin{array}{l}\text { PG I } \\
\text { V5 }\end{array}$ & $\begin{array}{l}\text { Cattle } \\
\text { Cattle }\end{array}$ & $\begin{array}{l}\text { D. G. ff. Edward* } \\
\text { A. W. Rodwell } \dagger\end{array}$ & $\stackrel{\operatorname{aPG} I}{-}$ \\
\hline $\begin{array}{l}\text { M. mycoides } \\
\text { var. capri }\end{array}$ & $\begin{array}{l}\text { PG 3 } \\
\text { pp. goat }\end{array}$ & $\begin{array}{l}\text { Goat } \\
\text { Goat }\end{array}$ & $\begin{array}{l}\text { D. G. ff. Edward* } \\
\text { E. Klieneberger-Nobel } \ddagger\end{array}$ & $\begin{array}{l}\text { aPG } 3 \\
\text { app }\end{array}$ \\
\hline Mycoplasma sp. & $\begin{array}{l}14 \\
Y\end{array}$ & $\begin{array}{l}\text { Goat } \\
\text { Goat }\end{array}$ & $\begin{array}{l}\text { M. E. Tourtellotte } \\
\text { A. W. Rodwell† }\end{array}$ & - \\
\hline M. gallisepticum & $\begin{array}{l}\text { A } 5969 \\
\text { s6 }\end{array}$ & $\begin{array}{l}\text { Chicken } \\
\text { Chicken }\end{array}$ & $\begin{array}{l}\text { M. E. Tourtellotte\$ } \\
\text { H. E. Adler\| }\end{array}$ & $\underline{59}$ \\
\hline M. gallinarum & $\mathbf{J}$ & Chicken & P. F. Smith & 一 \\
\hline Mycoplasma sp. & $\mathbf{R}$ & Chicken & R. Bernstein-Ziv** & aR \\
\hline
\end{tabular}

\section{METHODS}

Mycoplasma strains. The designation and source of the Mycoplasma strains examined are given in Table $\mathrm{I}$.

Media and growth conditions. A modified liquid Edward medium (Razin, 1963) was used. This medium was modified to contain $5 \%(\mathrm{v} / \mathrm{v})$ of pooled inactivated human serum for the propagation of organisms utilized as immunizing antigens. The medium used for growing organisms to obtain antigens for analysis contained $2 \%(\mathrm{v} / \mathrm{v})$ Difco-PPLO serum fraction instead of the human serum. One litre Roux bottles 
containing $500 \mathrm{ml}$. medium, or 2 to 4 litre Erlenmeyer flasks half filled with medium, were inoculated either with a I to $2 \%$ inoculum of an 18 to $24 \mathrm{hr}$ culture of the Mycoplasma laidlawii strains, or with a 5 to $10 \%$ inoculum of a 20 to $36 \mathrm{hr}$ culture of all the other strains. Cultures were incubated statically at $37^{\circ}$ under aerobic conditions. The organisms were harvested by centrifugation at $12,000 \mathrm{~g}$ for $10 \mathrm{~min}$., washed twice and resuspended in $0.25 \mathrm{M}-\mathrm{NaCl}$.

Preparation of antigens for rabbit immunization. Washed organisms were resuspended in $0.25 \mathrm{M}-\mathrm{NaCl}$ to a protein concentration of $20 \mathrm{mg} . / \mathrm{ml}$. as determined by the method of Lowry, Rosebrough, Farr \& Randall (195I). Thiomersalate in final concentration of ${ }^{10^{-4}}(\mathrm{w} / \mathrm{v})$ was added to prevent bacterial growth, and the suspension kept at $4^{\circ}$ until used. One volume of this suspension was added to an equal volume of Freund's complete adjuvant (Difco) and homogenized in the M.S.E. ultrasonic disintegrator $(60 \mathrm{~W} ., 20 \mathrm{kc}$.). The ultrasonic treatment was done in ice for $\mathrm{I}$ min. periods, with intervals to avoid heating. The white viscous emulsion obtained after treatment for 5 to Io min. was transferred into an hypodermic syringe by means of a spatula and kept at $4^{\circ}$ during the immunizing period.

Immunization of rabbits. Young rabbits $(\mathrm{I} .5$ to $2 \mathrm{~kg}$.) received two $0.5 \mathrm{ml}$. intramuscular injections of the antigen + adjuvant mixture into the hind leg at I week's interval. After a week rest $0.5 \mathrm{ml}$. of a suspension disrupted ultrasonically for I min., without adjuvant, was injected in the same manner, followed by a second injection of the same material 3 days later. The rabbits were bled 7 to Io days after the last injection and the serum was separated. Six weeks after bleeding the rabbits received two $0.5 \mathrm{ml}$. intramuscular booster injections of the cell suspension at an interval of 3 days. Rabbits were bled again on the I 4 th day after the last injection. The antisera collected were divided into $2 \mathrm{ml}$. portions and stored at $-20^{\circ}$. The list of antisera prepared is given in Table $\mathrm{I}$.

\section{Preparation of antigens for analysis}

Whole organism suspensions. Organisms grown in the PPLO-serum fraction supplemented medium were washed twice and resuspended in $0.25 \mathrm{M}-\mathrm{NaCl}$ to a concentration equiv. $20 \mathrm{mg}$. cell protein/ml.

Soluble cell proteins. The soluble cell proteins of the Mycoplasma laidlawii strains were liberated from the organisms by osmotic lysis (Razin, 1963). Washed packed organisms (about $100 \mathrm{mg}$. cell protein) were resuspended in $30 \mathrm{ml}$. of de-ionized water and incubated in a $37^{\circ}$ bath for $30 \mathrm{~min}$. Membranes and cell debris were sedimented at $35,000 \mathrm{~g}$ for $30 \mathrm{~min}$. at $10^{\circ}$, the supernatant fluid separated and again centrifuged as above. The concentration of protein in the supernatant fluid obtained was about $2 \mathrm{mg}$. $/ \mathrm{ml}$. The protein concentration was increased to $10 \mathrm{mg}$./ml. by perevaporation. Being more resistant to osmotic lysis, the other mycoplasmas were disrupted by ultrasonic treatment to liberate the soluble proteins. Suspensions of organisms in $0.25 \mathrm{M}$ $\mathrm{NaCl}$ were treated at $0^{\circ}$ in the disintegrator for 10 to $15 \mathrm{I}$-min. periods, with $2 \mathrm{~min}$. intervals to avoid heating. The soluble cell fraction was separated and concentrated as described above.

Solubilized cell membranes. Cell membranes obtained after osmotic lysis or ultrasonic disruption of the organisms were washed 4 to 5 times and resuspended in deionized water to a concentration of $20 \mathrm{mg}$. membrane protein $/ \mathrm{ml}$. The membrane suspension was mixed with an equal volume of $\mathrm{I} \%(\mathrm{w} / \mathrm{v})$ sodium dodecyl sulphate 
(SDS) (Razin, Morowitz \& Terry, 1965). The suspension cleared within $5 \mathrm{~min}$. of incubation at room temperature. A minute amount of insoluble material was removed by centrifugation at $37,000 \mathrm{~g}$ for $10 \mathrm{~min}$.

Defatted membrane protein. Lipid was removed from the membranes by butanol extraction at $0^{\circ}$ according to Rodwell, Razin, Rottem \& Argaman (1967). The hydrophobic protein fraction obtained was dissolved by SDS (I mg. detergent/mg. protein).

Hydrophobic membrane protein. This protein fraction was isolated by ammonium sulphate salting out of membranes solubilized in a mixture of SDS and sodium deoxycholate (Rodwell et al. 1967).

\section{Methods for antigenic analysis}

Agglutination of whole cell. This was carried out either on glass slides at room temperature or in test-tubes at $52^{\circ}$ according to Bailey et al. (I96I).

Double diffusion in agar. The test was done according to Ouchterlony (1964). Noble agar $\mathrm{I} \%(\mathrm{w} / \mathrm{v})$ was prepared in veronal $+\mathrm{HCl}$ buffer $(\mathrm{pH}=8.2$; ionic strength 0.05 Grabar, 1964). Microscope slides $(50 \times 75 \mathrm{~mm}$.) were covered with $5 \mathrm{ml}$. melted agar. Peripheral holes of $3 \mathrm{~mm}$. diameter and a central hole of $5 \mathrm{~mm}$. diameter were cut in the agar and were filled with 0.03 to $0.04 \mathrm{ml}$. of antiserum or antigen solution. Optimal precipitation lines were detected after 24 to $48 \mathrm{hr}$ incubation at $37^{\circ}$ in a damp chamber. The agar slides were washed for $48 \mathrm{hr}$ in $0.9 \%(\mathrm{w} / \mathrm{v}) \mathrm{NaCl}$ and then covered with filter paper and dried overnight at $37^{\circ}$. The dried slides were immersed for $20 \mathrm{~min}$. in $0.5 \%(w / v)$ aqueous nigrosin solution containing $5 \%(w / v)$ trichloroacetic acid and $5 \%(w / v)$ sulphosalicylic acid (Flechner \& Olitzki, 1966). Decolorization was accomplished by several washings of the slides in $2 \%$ acetic acid. For staining of proteins and lipids, the technique of Uriel (1964) was used. The slides were stained for $60 \mathrm{~min}$. in a Sudan Black IOB solution, decolorized in $50 \%(\mathrm{v} / \mathrm{v})$ ethanol in water, and then stained for $30 \mathrm{~min}$. in Azocarmine solution, and decolorized in $2 \%$ acetic acid. Lipids stained dark-blue and proteins red.

Microelectrophoresis and microimmunoelectrophoresis according to Scheidegger (1965). For microelectrophoresis, agar-covered slides were connected by filter-paper bridges to the reservoirs containing veronal $+\mathrm{HCl}$ buffer $(\mathrm{pH} \mathrm{8.2)}$. The cell protein solutions to be analysed were introduced into the $3 \mathrm{~mm}$. diameter holes cut in the agar across the centre of the slide. Current $(5 \mathrm{~V} / \mathrm{cm}$.) was applied for $60 \mathrm{~min}$. For immunoelectrophoresis two trenches, $2 \mathrm{~mm}$. wide, were cut in parallel to the protein pattern at a $5 \mathrm{~mm}$. distance from the sample hole. Antisera were introduced into the trenches and results were read after incubation at $37^{\circ}$ for $48 \mathrm{hr}$ in a damp chamber. Precipitation lines were detected either by direct illumination or after staining with nigrosin.

Transmigration. The method described by Calliford (1964) was used with a slight modification. Two parallel rows of $3 \mathrm{~mm}$. holes were cut at $1 \mathrm{~cm}$. distance in an agarcovered slide. The antigen solutions $(0.03$ to $0.04 \mathrm{ml}$.) were put in one row, and the antisera $(0.03$ to $0.04 \mathrm{ml}$.) in the other row. The agar-covered slides were connected to the buffer reservoirs as described for microimmunoelectrophoresis. The antisera row was on the anode side. An electric current (5 V/cm.) was applied for $60 \mathrm{~min}$. Antigen antibody precipitates were formed in the interspace between the rows.

Immunoelectrophoresis on cellulose acetate strips was done according to Flechner \& Olitzki (1966) using tris + EDTA + boric acid buffer (pH 8.9; Aronsson \& Grönwall, 1957). 
Polyacrylamide-gel electrophoresis and immunoelectrophoresis. The gel system consisted of $7.5 \%$ Cyanogum 4I (a mixture of acrylamide, $95 \%$, and $N, N^{\prime}$-methylenebisacrylamide, $5 \%$, supplied by E-C Apparatus Co. Philadelphia, Pennsylvania, U.S.A.) in $0.25 \mathrm{M}$-tris $+\mathrm{HCl}$ buffer ( $\mathrm{pH} \mathrm{8.3).} \mathrm{Polymerization} \mathrm{was} \mathrm{induced} \mathrm{by} \mathrm{adding}$ $0.05 \mathrm{ml}$. $N, N, N^{\prime}, N^{\prime}$-tetramethylethylenediamine and $25 \mathrm{mg}$. ammonium persulphate to $10 \mathrm{ml}$. of Cyanogum solution. Samples (50 to $100 \mu \mathrm{l}$. containing 150 to $300 \mu \mathrm{g}$. protein) were put on top of the gels and mixed with $50 \mu \mathrm{l}$. of a $40 \%(\mathrm{w} / \mathrm{v})$ sucrose solution in the electrophoresis buffer (tris + EDTA + boric acid, $\mathrm{pH} \mathrm{8.9,} \mathrm{diluted} \mathrm{I} / \mathrm{IO}$ in de-ionized water). The tubes were then filled with the dilute buffer and electrophoresis done at room temperature for $2 \mathrm{hr}$ at a constant current of $5 \mathrm{~mA} /$ tube, with the lower electrode as anode. The gels were stained for $30 \mathrm{~min}$. in $1 \%(w / v)$ Amido Black $10 B$ in $7 \%$ (v/v) acetic acid. Destaining was done electrolytically in $7 \%$ acetic acid (Razin, 1968). For immunodiffusion, protein samples were run in triplicate. One of the gels was stained to locate the protein bands. Another gel was cut along its long axis, and the two halves were laid on an agar-covered slide, on both sides of a trench filled with antiserum. The third gel was cut transversally into $5 \mathrm{~mm}$. slices which were put sequentially between two trenches filled with antiserum. The slides were incubated at $37^{\circ}$ for 48 to $72 \mathrm{hr}$ and precipitation lines were detected in diffuse light or after staining with nigrosin.

\section{RESULTS}

\section{Agglutination of whole Mycoplasma organisms by antisera}

The simple slide-agglutination technique separated the Mycoplasma strains into several distinct groups. One group included the Mycoplasma laidlawii strains and the other the bovine and caprine strains. The avian mycoplasmas were serologically heterogeneous; thus the $M$. gallisepticum strains and the avian strain J were not agglutinated by antiserum against strain $R$, and vice versa. The results obtained by the tube-agglutination technique confirmed those obtained by slide agglutination (Table 2).

Table 2. Tube agglutination titre of whole Mycoplasmas in $0.25 \mathrm{M}-\mathrm{NaCl}$

\begin{tabular}{|c|c|c|c|c|c|c|}
\hline \multirow[b]{2}{*}{ Organism } & \multicolumn{6}{|c|}{ Antisera } \\
\hline & $\mathbf{a A}$ & aB & aOR & app & aPG I & aR \\
\hline M. laidlawii A & $16-32 *$ & 2 & 8 & 0 & 0 & 0 \\
\hline M. laidlawii в & 2 & 16 & 2 & 0 & 0 & 0 \\
\hline M. laidlawii $\mathrm{OR}$ & $4-8$ & 2 & 8 & 0 & 0 & 0 \\
\hline M. mycoides var. mycoides PG I & 0 & 0 & o & 4-8 & 256 & o \\
\hline M. mycoides var. capri pp. goat & 0 & o & 0 & $32-64$ & 8 & 0 \\
\hline M. mycoides var. capri $\mathrm{PG} 3$ & 0 & 0 & $\mathbf{0}$ & 16 & 8 & 0 \\
\hline Mycoplasma sp. avian strain $\mathbf{R}$ & 0 & $\mathbf{0}$ & 0 & o & 0 & 128 \\
\hline
\end{tabular}

\section{Gel-diffusion precipitin reactions with soluble cell proteins}

Transmigration. This technique permitted the rapid determination of the serological relationships of the soluble cell proteins of the various Mycoplasma strains (Fig. I). The results corresponded well with those obtained by agglutination of whole organisms. No cross-reactions were evident between the Mycoplasma laidlawii and the bovine, caprine or avian strains. On the other hand Fig. I shows common antigens within the serological groups. Thus $M$. laidlawii strains B and oR reacted with the 
antiserum prepared against $M$. laidlawii strain $\mathrm{A}$, and $M$. mycoides var. mycoides reacted with the antiserum prepared against $M$. mycoides var. capri. No cross-reactions were seen between $M$. gallisepticum and the other avian strains.

Agar double diffusion. This method gave a more detailed picture of the serological relationships between the mycoplasmas. The results corresponded well with those

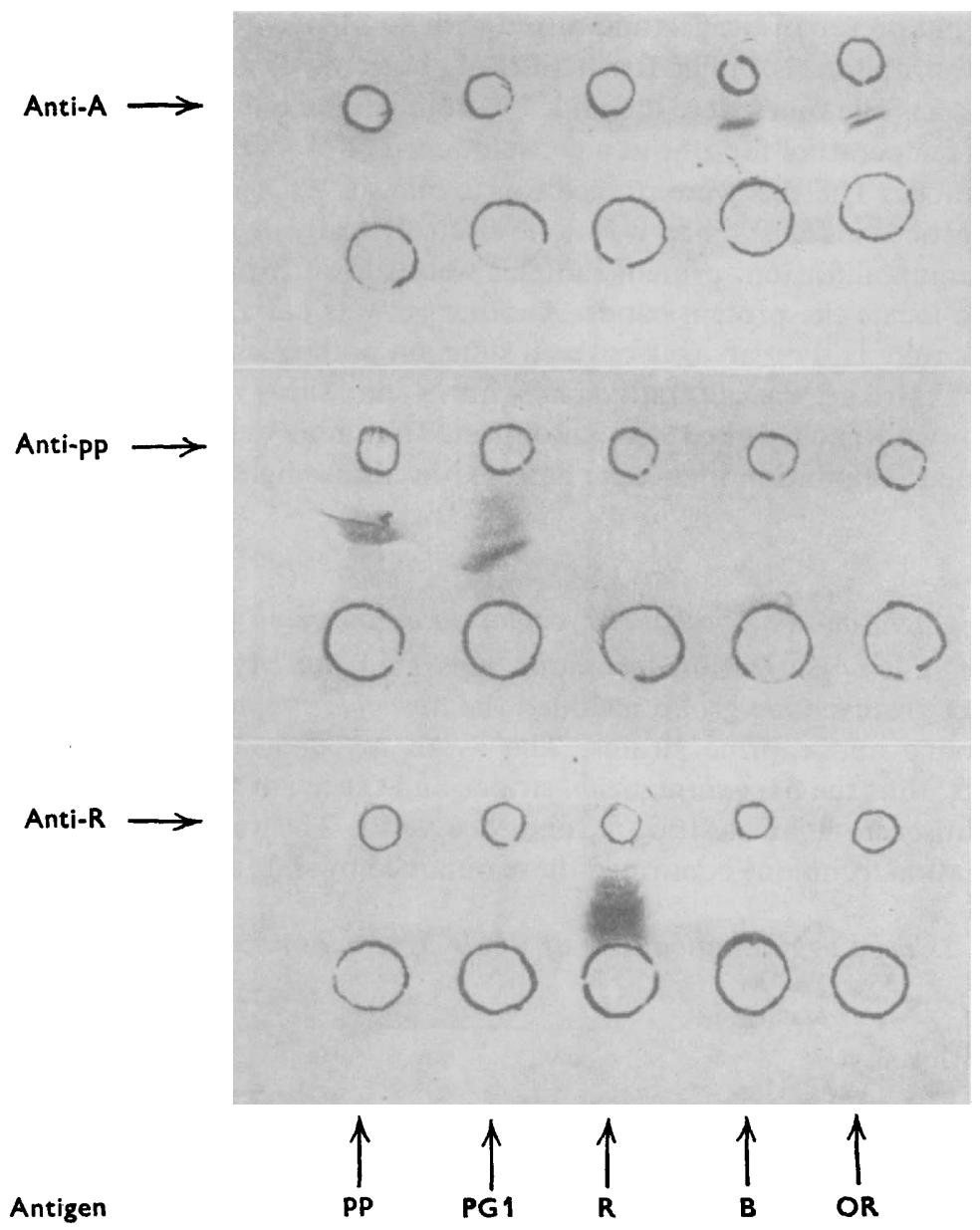

Fig. I. Precipitation lines formed by transmigration of soluble cell proteins of various mycoplasmas against specific antisera. Antigens analysed (large holes) were obtained from $M y c o-$ plasma mycoides var. capri, pp. goat, $M$. mycoides var. mycoides PG I, Mycoplasma sp. avian strain $\mathbf{R}, M$. laidlawii strains B and $\mathrm{OR}$.

obtained by the rapid transmigration technique. Table 3 and Fig. 2 show the different serological groups and the close serological interrelationships of strains within the groups. In order to check the specificity of the precipitation lines, all antigens used were tested against normal rabbit serum; no precipitation lines were formed with any of the antigens. Furthermore, all our antisera were tested for preciptation with the growth medium used to prepare the antigens for analysis, and the results were all negative. 
Microimmunoelectrophoresis. Optimal conditions for electrophoresis were determined by testing the solubility and electromigration of the soluble cell proteins of the various mycoplasmas at $\mathrm{pH}$ values ranging from $2 \cdot 3$ to $\mathrm{II} \cdot 5$. The soluble cell proteins

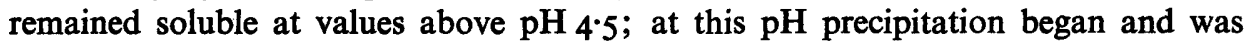
complete at about $\mathrm{pH}_{3.5}$. Only the proteins of the Mycoplasma gallisepticum strains began to precipitate at $\mathrm{pH} 2 \cdot 3$. Optimal conditions for electromigration of the soluble

Table 3. Mycoplasma gel-diffusion precipitin reactions of soluble cell proteins

\begin{tabular}{|c|c|c|c|c|c|c|c|c|}
\hline \multirow[b]{2}{*}{ Soluble proteins of: } & \multicolumn{8}{|c|}{ Antiserum } \\
\hline & aA & ав & aOR & app & APG I & aPG 3 & a 59 & aR \\
\hline M. laidlawii A & $4^{*}$ & 2 & 3 & - & - & - & - & - \\
\hline M. laidlawii В & $3-4$ & $3-4$ & 3 & - & - & - & - & - \\
\hline M. laidlawii OR & 3 & 3 & $3-4$ & - & - & - & - & 一 \\
\hline M. mycoides var. mycoides PG I & 二 & - & - & 3 & $4-5$ & ND & - & - \\
\hline M. mycoides var. mycoides v5 & 一 & - & $\longrightarrow$ & 3 & 3 & 3 & - & - \\
\hline M. mycoides var. capri, pp. goat & - & - & - & $5-6$ & $3-4$ & $2-3$ & 一 & 一 \\
\hline M. mycoides var. capri $\mathrm{PG} 3$ & 一 & - & 一 & $2-3$ & 3 & $3-4$ & - & 一 \\
\hline Mycoplasma sp. strain $\mathbf{Y}$ & 一 & 一 & - & $2-3$ & 3 & 3 & - & - \\
\hline Mycoplasma sp. strain I4 & - & - & 一 & $3-4$ & $2-3$ & $2-3$ & - & - \\
\hline M. gallisepticum A 5969 & - & - & - & - & - & - & 4 & - \\
\hline M. gallisepticum s 6 & - & - & - & $\longrightarrow$ & - & - & $2-3$ & - \\
\hline Mycoplasma sp. avian strain R & - & - & - & - & - & - & - & $4-5$ \\
\hline M. gallinarum strain $\mathrm{J}$ & - & - & - & - & - & - & - & - \\
\hline
\end{tabular}

* Maximum number of precipitation lines is given. Precipitation lines caused by homologous antisera are shown in italic.

ND, not done; -, no precipitation lines.

proteins were therefore tested in the range of $6 \cdot 0$ to $9 \cdot 0$, with several buffers. The best protein migration and separation was achieved in veronal $+\mathrm{HCl}$ buffer (Grabar, 1964) at $\mathrm{pH} \mathrm{8.3.} \mathrm{At} \mathrm{this} \mathrm{pH}$ value most of the proteins migrated towards the anode, except those of $M$. gallisepticum which migrated toward the cathode. Figure 3 shows the serological cross-reactions between the $M$. laidlawii strains by the microimmunoelectrophoresis technique. All antigens migrated towards the anode, while in $M$. mycoides var. capri, analysed under the same conditions, some antigens migrated towards the cathode. The bovine, caprine and avian strains also revealed more precipitation lines than the $M$. laidlawii strains.

Immunoelectrophoresis on cellulose acetate strips. Electrophoresis of the soluble cell proteins of all the mycoplasmas excep, Mycoplasma laidlawii separated them into 6 to 8 fractions on the cellulose acetate strips. The soluble proteins of $M$. laidlawii did not separate well by this technique. Immunoprecipitation lines were formed under the cellulose acetate strips, but were fewer and weaker than those obtained by agar microimmunoelectrophoresis, and were shared by all protein fractions.

Polyacrylamide-gel immunoelectrophoresis. Electrophoresis of the soluble proteins separated them into several diffuse fractions. Sectioned gels transferred to agarcovered slides for diffusion against antisera, showed similar precipitation lines as were obtained by agar immunoelectrophoresis, i.e. the precipitation lines ran along most of the electrophoretic pattern (Fig. 4). 


\section{Antigenicity of the cell membrane}

Whole membranes. Solubilization of the membranes is a prerequisite for their immunological analysis by immunodiffusion techniques. The detergent sodium dodecyl sulphate (SDS) was found to be most efficient in solubilizing mycoplasma membranes (Razin et al. 1965). However, in the concentration used for membrane solubilization SDS precipitated some of the rabbit serum proteins. The antisera tested were therefore

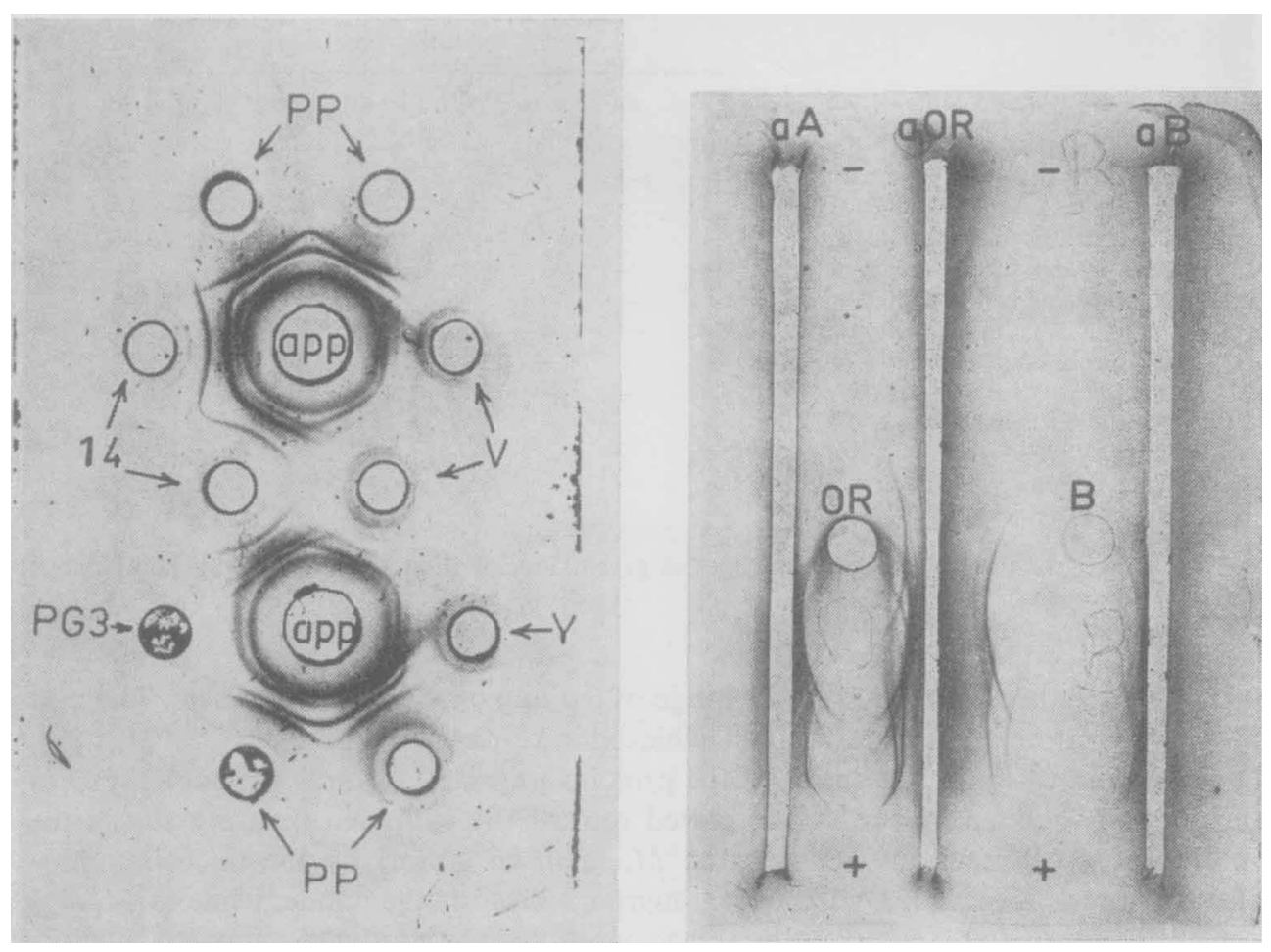

Fig. 2

Fig. 3

Fig. 2. Antigenic relationship of the soluble cell proteins of caprine and bovine mycoplasmas. Central holes contain antiserum to Mycoplasma mycoides var. capri pp. goat (app). Peripheral holes contain soluble cell proteins of $M$. mycoides var. capri pp. goat (PP), Mycoplasma sp. strain Y, M. mycoides var. capri PG 3, M. mycoides var. mycoides v 5 (V), Mycoplasma sp. strain 14.

Fig. 3. Antigenic relationship of the soluble cell proteins of Mycoplasma laidlawii strains shown by microimmunoelectrophoresis. Holes contain soluble cell proteins of $M$. laidlawii strains $O_{R}$ and strain $\mathrm{B}$. Trenches contain antiserum to $M$. laidlawii strains A $(\mathrm{aA}), M$. laidlawii strain OR (aOR), and $M$. laidlawii strain B (aB).

pretreated with $1 \%(\mathrm{w} / \mathrm{v}) \mathrm{SDS}$ at $37^{\circ}$ for $60 \mathrm{~min}$. and the precipitate formed was removed by centrifugation. No further precipitate was formed on a longer incubation time, or by addition of more SDS to the treated sera. This treatment did not cause any detectable loss of antiserum potency (see also Jaquet, Bloom \& Cebra, 1964). Table 4 shows that the solubilized Mycoplasma membranes formed between I to 3 precipitation lines with the homologous antiserum to whole organisms, indicating that the mem- 
branes retained their antigenic group specificity as shown by whole cells (Table 2), and soluble cell proteins (Table 3). Reactions with SDS-treated normal rabbit serum, or with SDS alone, were always negative. Membranes of $M$. laidlawii solubilized in
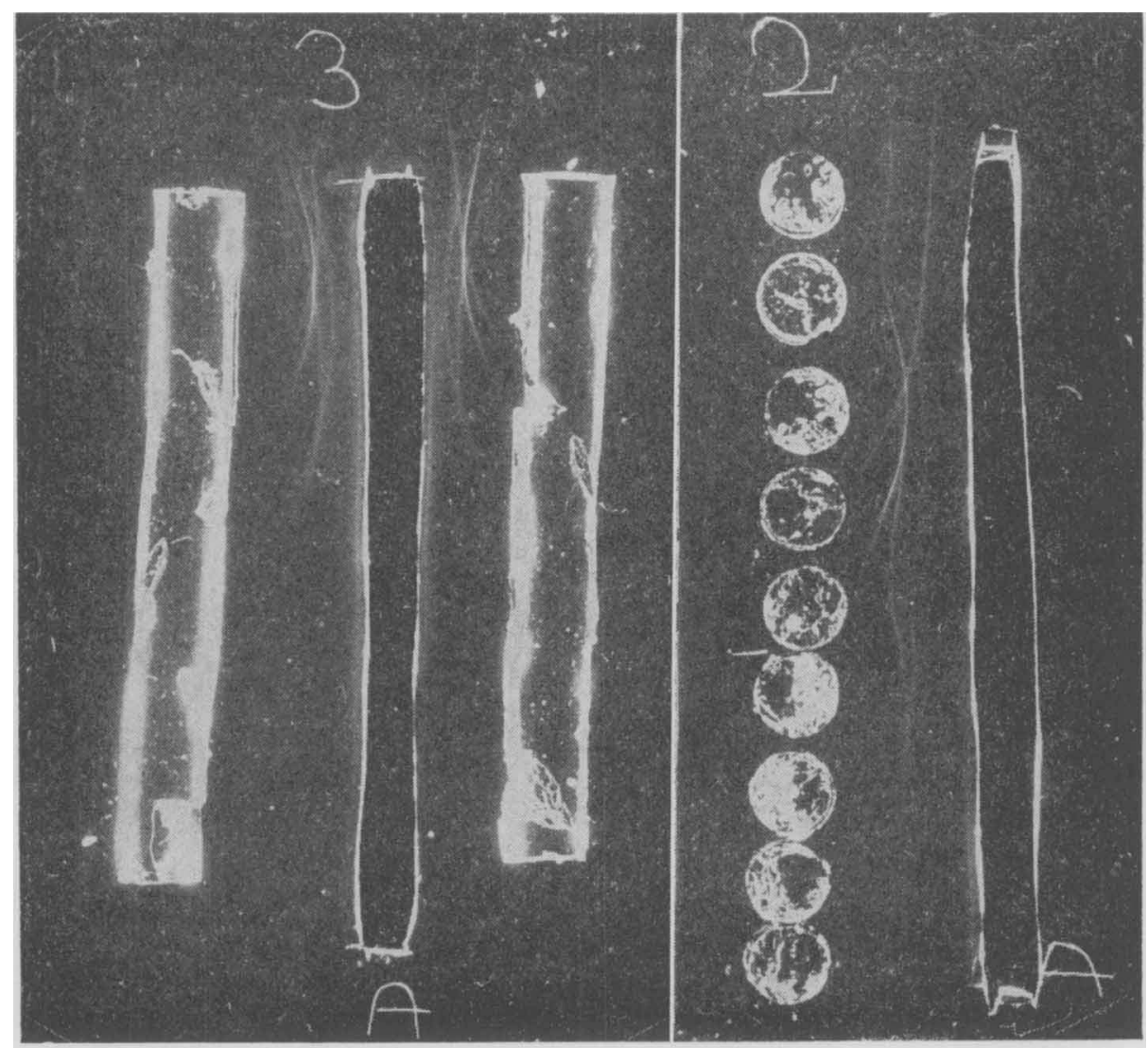

Fig. 4. Polyacrylamide-gel immunoelectrophoresis of soluble cell proteins of Mycoplasma laidlawii strain $\mathrm{OR}$. The trenches were filled with antiserum to $M$. laidlawii strain A. The gel to the left was sectioned after electrophoresis along its long axis into two halves, while the gel to the right was sectioned transversally.

Table 4. Agar double-diffusion reactions of SDS-solubilized mycoplasma membranes with antisera to whole cells

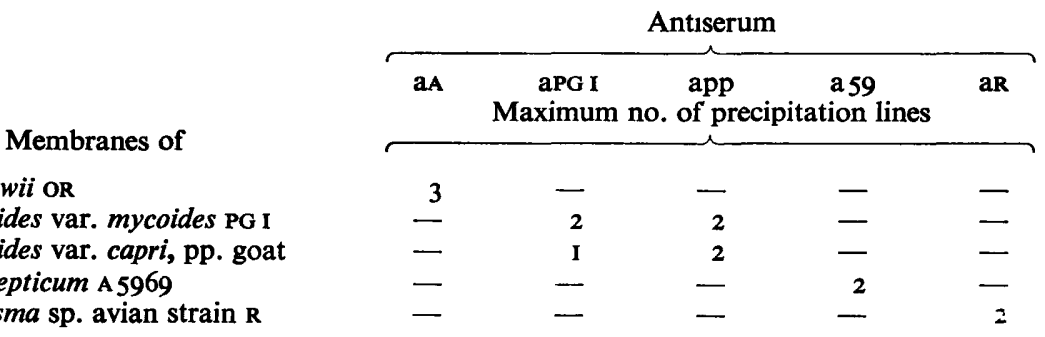

-, No precipitation lines. 
SDS were also subjected to polyacrylamide gel electrophoresis; a few protein bands were resolved. Unstained gels, run simultaneously, were sliced and tested by immunodiffusion against whole-cell antiserum. Two or three precipitation lines appeared (Fig. 5). Soluble cell proteins of several Mycoplasma strains were mixed with SDS at the same concentration used for membrane solubilization. In gel-diffusion tests the SDS-treated material exhibited similar precipitation lines as the untreated soluble proteins.

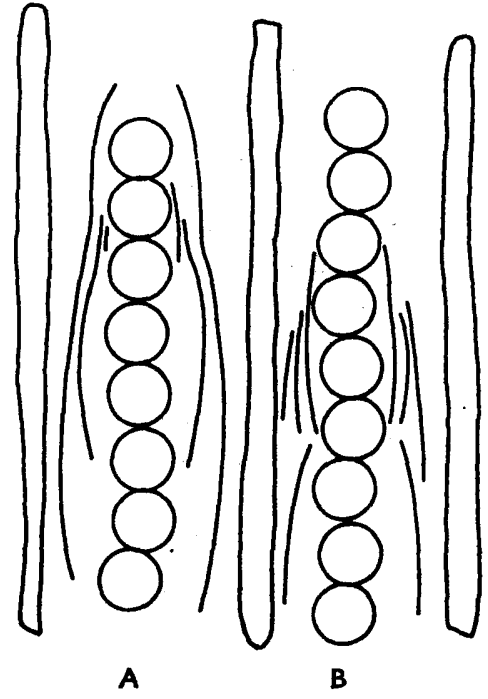

Fig. 5

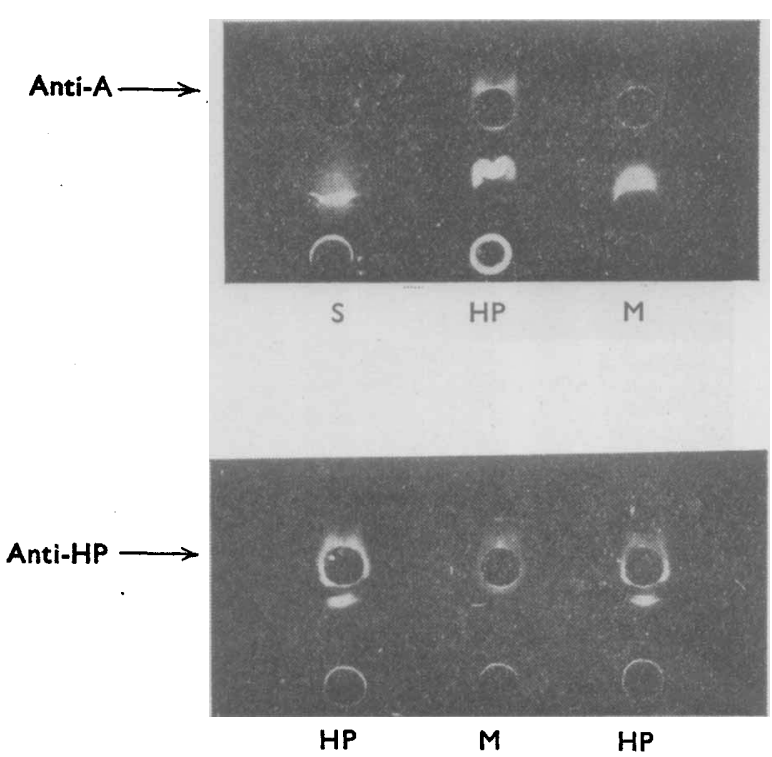

Fig. 6

Fig. 5. Polyacrylamide-gel immunoelectrophoresis of Mycoplasma laidlawii or membrane proteins. The gels were sectioned transversally after electrophoresis, and the trenches were filled with antiserum to $M$. laidlawii strain $A$. $A=$ membranes solubilized in SDS. B = butanol-extracted membrane proteins solubilized in SDS.

Fig. 6. Precipitation lines formed by transmigration of hydrophobic membrane protein (HP), whole membranes (M), and soluble cell proteins (S) of Mycoplasma laidlawii OR against antiserum to whole cells of $\boldsymbol{M}$. laidlawii strain A (upper part of figure) and against antiserum to hydrophobic protein (lower part of figure). All preparations were dissolved in SDS.

Butanol-extracted membranes. Li pid-free butanol-extracted membrane proteins solubilized in SDS were electrophorized in alkaline polyacrylamide gels. As with whole membranes, the immunodiffusion of the sectioned gels revealed several precipitation lines (Fig. 5).

Hydrophobic membrane proteins. An antiserum produced in rabbits against the hydrophobic membrane protein of Mycoplasma laidlawii was tested by transmigration against the hydrophobic protein fraction, whole membranes, and soluble cell protein solubilized in SDS. The same antigens were simultaneously tested against an antiserum to whole organisms. Figure 6 shows that the hydrophobic protein fraction reacted with both its homologous and whole-organism antiserum. However, membrane proteins and soluble cell proteins (not shown in Fig. 6) reacted only with the whole-organism antiserum . 
Membrane lipids. The staining method suggested by Uriel (1964) was used to detect protein and lipid components in the precipitation lines. The precipitation lines formed by soluble cell proteins, treated or untreated with SDS and tested against SDS-treated antisera, did not stain for lipid; a heavy precipitation line obtained with solubilized membranes did stain intensively. Membrane lipids extracted from Mycoplasma laidlawii according to Folch, Lees \& Sloane-Stanley (1957) were solubilized in tris $+\mathbf{H C l}+$ EDTA buffer (pH 7.7) containing $\mathrm{I} \%$ (w/v) SDS. The lipid solution tested by gel diffusion against the SDS treated antisera to the various mycoplasma groups reacted by forming Sudan Black-positive precipitation lines with several of the antisera and showed none of the $M$. laidlawii group antigenic specificity.

\section{DISCUSSION}

Most of the mycoplasma strains included in the present study fell into two distinct serological groups: one included the Mycoplasma laidlawii strains and the other the bovine and caprine strains. The avian mycoplasma studied were serologically heterogeneous. The close serological relationship between $M$. laidlawii strains $A$ and $B$ is well known. Although originally these strains were separated on serological grounds (Laidlaw \& Elford, 1936) they were indistinguishable by the complement-fixation test (Lemcke, 1964). Nevertheless, Clyde (1964) noticed that the growth of the two strains was suppressed by both their homologous and heterologous antisera, but that the inhibition zones produced by the heterologous antisera were only half as wide as those produced by the homologous antiserum. This finding has been confirmed by us (unpublished). The electrophoretic patterns of membrane proteins of the two strains were similar, but not identical (Rottem \& Razin, 1967). Nucleic acid homology tests showed about $70 \%$ homology between the DNA of both strains (McGee, Rogul \& Wittler, 1967). All the evidence, with that of the present study, indicates that $M$. laidlawii A and B strains are closely related but not identical. The present serological data also substantiate the findings by the electrophoretic technique that the $M$. laidlawii strain OR, isolated from the human oral cavity, is related to or identical with $M$. laidlawii strain A (Rottem \& Razin, 1967).

The bovine and caprine mycoplasma strains included in our study, form a closely related group. The caprine strains resemble each other in their heavy growth and tendency to lyse and form sticky precipitates when the cultures age. When cell proteins of the caprine and bovine strains were subjected to polyacrylamide-gel electrophoresis very similar electrophoretic patterns were revealed (Razin, I968). Lemcke (I965) by using the gel precipitin technique showed that Mycoplasma mycoides var. mycoides and $M$. mycoides var. capri (pp. goat) have certain antigenic components in common. All these results speak in favour of regarding the caprine strains tested as varieties of Mycoplasma mycoides.

The few avian strains included in our study did not form a serological group. The Mycoplasma gallisepticum A 5969 and s6 strains showed antigenic similarity. The electrophoretic patterns of their membrane proteins were almost identical (Rottem \& Razin, 1967). However, these strains had no antigenic components in common with the two other avian strains $\mathrm{J}$ and $\mathrm{R}$, which were also clearly differentiated by the electrophoretic technique (Rottem \& Razin, 1967; Razin, 1968).

The present study provides some information on the electrophoretic properties of 
the soluble cell proteins of mycoplasmas. The proteins of the Mycoplasma laidlawii strains consistently showed a higher electrophoretic homogeneity than the proteins of the other strains, as shown by the non-separation of protein fractions by electrophoresis on cellulose acetate strips and by the few protein bands appearing upon electrophoresis of the $M$. laidlawii soluble proteins in alkaline polyacrylamide gels. In microimmunoelectrophoresis tests at $\mathrm{pH} 8 \cdot 3$, all the soluble $M$. laidlawii proteins moved towards the anode, resulting in poor separation and formation of a few precipitation lines. The soluble cell proteins of the other mycoplasmas showed more electrophoretic heterogeneity. Thus even at $\mathrm{pH} \mathrm{8.3} \mathrm{part} \mathrm{of} \mathrm{the} \mathrm{proteins} \mathrm{of} M$. mycoides var. capri moved towards the cathode, leading to better separation, and the identification of more precipitation lines. The migration of most of the $M$. gallisepticum soluble proteins to the cathode at $\mathrm{pH} 8 \cdot 3$ indicates their highly basic nature.

The solubilization of Mycoplasma cell membranes by sodium dodecyl sulphate (SDS) permitted the antigenic analysis of membrane proteins. SDS did not destroy the antigenic activity of at least part of the membrane proteins, as shown by immunodiffusion tests. Precipitin reactions done with solubilized membranes revealed the same serological group-specificity as shown by the soluble cell proteins, although fewer precipitation lines were produced. Staining with Sudan Black indicated that membrane lipids also took part in the precipitin reaction, either as such or in association with protein. Mycoplasma laidlawii membrane lipids extracted with chloroform + methanol formed a Sudan Black-stained precipitation line when tested against antiserum to $M$. laidlawii. However, a similar precipitation line was also formed with heterologous antisera, indicating that $M$. laidlawii lipids do not possess the antigenic specificity shown by membrane proteins. Kenny (1967) showed that lipids extracted from $M$. hominis, $M$. arthritidis and $M$. pulmonis cross-reacted in complement-fixation tests, while lipids of $M$. pneumoniae and $M$. fermentans were serologically species-specific. The possibility of protein denaturation by SDS should be considered. There is little doubt that at the concentration used for membrane solubilization, the SDS causes conformational changes at least in some membrane proteins (Shapiro, Vinuela \& Maizel, 1967). Thus, the adenosine triphosphatase activity of Mycoplasma membranes was lost during solubilization by SDS (Rottem \& Razin, 1966). However, SDS did not affect the NADH oxidase activity of the solubilized membranes (Razin et al. 1965) indicating a different degree of sensitivity of different membrane proteins to the denaturating effects of SDS. An indication that SDS at the concentration used does not radically alter the antigenic properties of cell proteins is found in that SDS-treated soluble cell proteins of several mycoplasmas exhibited similar precipitation lines as untreated soluble proteins. Mommaerts (1967) showed by measurements of circular dichroism that SDS, at a concentration similar to that used by us, did not significantly change the conformation of proteins of sarcotubular membranes. Treatment by SDS did not destroy the immunogenic activity of at least part of the mycoplasmal membrane proteins (the hydrophobic protein fraction). However, the antiserum to the protein fraction did not react with the soluble cell proteins, or with whole membranes solubilized with SDS. This might indicate a change in the antigenic properties of the hydrophobic membrane proteins during their isolation by SDS action. It may be concluded that in spite of possible artifacts arising from conformational changes in some membrane proteins, solubilization of Mycoplasma membranes by detergents may allow the further antigenic analysis of membrane proteins. 
This work formed part of an investigation made by M. Argaman in partial fulfilment of the requirements for the Ph.D. degree at the Hebrew University, Jerusalem. Our thanks are due to Dr J. Flechner for advice and stimulating discussions. The work was financed in part by grant no. FG-Is-I 74 made by the United States Department of Agriculture under P.L. 480.

\section{REFERENCES}

Aronsson, T. \& GRöNwall, A. (1957). Improved separation of serum proteins in paper electrophoresis-a new electrophoresis buffer. Scand. J. clin. Lab. Invest. 9, 338.

Bailey, J. S., Clark, H. W., Felts, W. R., Fowler, R. C. \& Brown, T. MCP. (196I). Antigenic properties of pleuropneumonia-like organisms from tissue cell cultures and the human genital area. J. Bact. 82, 542.

CALLIFORD, B. J. (1964). Precipitin reactions in forensic problems. Nature, Lond. 201 , 1092.

CL YDE, W. A., JUN. (1964).Mycoplasma species identification based upon growth inhibition by specific antisera. J. Immun. 92, 958.

DeEB, B. J. \& KeNNY, G. E. (1967). Characterization of Mycoplasma pulmonis variants isolated from rabbits. II. Basis for differentiation of antigenic subtypes. J. Bact. 93, 1425.

Edward, D. G. ff., Freundt, E. A., Chanock, R. M., Fabricant, J., Hayflick, L., Lemcke, R. M., RAZIN, S., Somerson, N. L. \& WITTLER, R. G. (1967). Recommendations on nomenclature of the order Mycoplasmatales. Science, N.Y. 155, 1694.

FLECHNER, J. \& OLITZKI, A. L. (I966). Resolution of the rabbit immunoglobulins into multiple components by electrophoresis on cellulose acetate. Life Sci. $5,495$.

Folch, J., Lees, M. \& Sloane-Stanley, G. H. (1957). A simple method for the isolation and purification of total lipids from animal tissues. J. biol. Chem. 226, 497.

GraBAR, P. (1964). Immunoelectrophoretic analysis. In Immunological Methods. Ed. by J. F. Ackroyd. p. 79. Oxford: Blackwell Scientific Publications.

JAQUET, H., BlOOM, B. \& CEBRA, J. J. (1964). The reductive dissociation of rabbit immune globulin in sodium dodecyl sulfate. J. Immun. 92, 991.

KENNY, G. E. (1967). Heat-lability and organic solvent-solubility of Mycoplasma antigens. Ann. N.Y. Acad. Sci. $143,676$.

KenNY, G. E. \& Grayston, J. T. (1965). Eaton pleuropneumonia-like organism (Mycoplasma pneumoniae) complement-fixing antigens: extraction with organic solvents. J. Immun. 95 , 19.

LAIDLAW, P. P. \& Elford, W. J. (1936). A new group of filterable organisms. Proc. Roy. Soc. B 120, 292.

LEMCKE, R. M. (1964). The serological differentiation of Mycoplasma strains (pleuropneumonia-like organisms) from various sources. J. Hyg., Camb. 62, 199.

LEMCKE, R. M. (1965). A serological comparison of various species of Mycoplasma by an agar gel double-diffusion technique. J. gen. Microbiol. 38, 9 I.

LemCKe, R. M. \& Hollingdale, M. R. (1968). Preliminary observations on the antigens of Mycoplasma hominis. Proc. Soc. gen. Microbiol. 53, ii.

LemCKe, R. M., MARMmon, B. P. \& PlACKetT, P. (1967). Immunochemical analysis of Mycoplasma pneumoniae. Ann. N.Y. Acad. Sci. 143, 691.

Lowry, O. H., Rosebrough, N. J., Farr, A. L. \& Randall, R. J. (195I). Protein measurement with the Folin phenol reagent. J. biol. Chem. 193, 265.

Marmion, B. P., PlacketT, P. \& LemCKe, R. M. (I967). Immunochemical analysis of Mycoplasma pneumoniae. I. Method of extraction and reaction of proteins from $M$. pneumoniae and $M$. mycoides with homologous antisera and with antisera against Streptococcus MG. Aust. J. exp. Biol. Med. Sci. 45, 163.

MCGeE, Z. A., RoGUL, M. \& WITTLER, R. G. (1967). Molecular genetic studies of relationships among Mycoplasma, L-forms and bacteria. Ann. N.Y. Acad. Sci. 143, 21.

MommaERTS, W. F. H. M. (1967). Conformational studies on the membrane protein of sarcotubular vesicles. Proc. natn. Acad. Sci. U.S.A. 58, 2476.

OUCHTERLONY, Ö. (1964). Gel diffusion techniques. In Immunological Methods. Ed. by J. F. Ackroyd. p. 55. Oxford: Blackwell Scientific Publications. 
Prescott, B., Sobeslavsky, O., Caldes, G. \& Chanock, R. M. (1966). Isolation and characterization of fractions of Mycoplasma pneumoniae. I. Chemical and chromatographic separation. J. Bact. 9r, 2117.

RAzIN, S. (1963). Osmotic lysis of Mycoplasma. J. gen. Microbiol. 33, 47I.

RAzIN, S. (I968). Mycoplasma taxonomy studied by electrophoresis of cell proteins. J. Bact. 96, 687.

RAzIN, S. \& RoTrem, S. (1967). Identification of Mycoplasma and other microorganisms by polyacrylamide-gel electrophoresis of cell proteins. J. Bact. 94, 1807.

RAzIN, S., MorowItz, H. J. \& TeRRY, T. M. (1965). Membrane subunits of Mycoplasma laidlawii and their assembly to membrane-like structures. Proc. natn. Acad. Sci., U.S.A. 54, 219.

Rodwell, A. W., Razin, S., Rottem, S. \& ARGaman, M. (1967). Association of protein and lipid in Mycoplasma laidlawii membranes disaggregated by detergents. Arch Biochem. Biophys. 122, 621.

Rotrem, S. \& RAZIN, S. (1966). Adenosine triphosphatase activity of Mycoplasma membranes. J. Bact. 92, 714.

RotTEM, S. \& RAZIN, S. (1967). Electrophoretic patterns of membrane proteins of Mycoplasma. J. Bact. 94, 359.

SCHEIDEGGRR, J. J. (1965). Une micro-méthode de l'immunoelectrophorese. Int. Archs Allergy appl. Immun. 7, 103.

Shapiro, A. L., Vinuela, E. \& Maizel, J. V. (1967). Molecular weight estimation of polypeptide chains by electrophoresis in SDS-polyacrylamide gels. Biochem. biophys. Res. Comm. 28, 815.

Sobeslaysky, O., Prescott, B., James, W. D. \& Chanock, R. M. (1966). Isolation and characterization of fractions of Mycoplasma pneumoniae. II. Antigenicity and immunogenicity. J. Bact. 9I, $2 \mathrm{I} 26$.

URIEL, J. (1964). The characterization reactions of the protein constituents following electrophoresis or immuno-electrophoresis in agar. In Immuno-Electrophoretic Analysis. Ed. by P. Grabar and P. Burtin. p. 30. Amsterdam: Elsevier Publishing Co.

Williams, M. H. \& TAYLOR-RoBinson, D. (1967). Antigenicity of Mycoplasma membranes. Nature, Lond. 215, 973. 